ISSN: 2036-5438

\title{
From the Unitary Patent Package to a Federal EU Patent Law
}

by

Juliana Almeida and Guilherme Oliveira e Costa* 


\begin{abstract}
For the last forty years, the European Union has been pursuing the goal of a unified system of patent law, which would make it possible for an invention to be protected, by EU law, throughout the territory of the Member-States, with a single application. This would simplify the patent protection system, making it easier, less costly and more secure, and would facilitate access to the internal market and promote scientific and technological development. However, problems might arise because of the plurality of legal sources that could be involved and due to the fact that not all countries want to be part of this new system. Nevertheless, the involvement of the majority of the Member-States in the Unitary Patent Package, through participating in an international agreement and in using the EU's enhanced cooperation mechanism, is evidence of federalist manifestations of the EU as a sui generis organisation.
\end{abstract}

\title{
Key-words
}

Unitary Patent System, patents, federalism, European Union 


\section{Introduction}

The goal of a unified system of patent law in the European Union (EU) has been pursued, by European institutions and Member-States, over the last forty years. The aim is to have an EU law that protects an invention throughout the territory of the MemberStates with a single application. A simplified patent protection system would make the process easier, less costly and more secure. It would also facilitate access to the internal market and promote scientific and technological development, objectives of the EU.

One can easily understand that such a scenario has a number of advantages, both from a legal and an economic point of view, especially in the context of a single market like the European Union, making it more competitive compared to other global powers. Nevertheless, in Europe, the development of patent law has not been promoted by the EU, but, instead, by different European countries as sovereign subjects of Public International Law; this has led us to a patent system which is extremely complex and fragmented.

As an attempt to reformulate and redesign patent law and establish it as EU law, the Unitary Patent Package ${ }^{\mathrm{I}}$ (UPP) was developed by EU institutions. Clearly influenced by the patent law of the United States of America (USA), the UPP intends to introduce in the EU a unitary patent system which is, in our understanding, a federal manifestation of the postLisbon EU.

With this in mind, this paper aims, firstly, to critically compare the UPP and its components with the system currently in force and to explain its probable impact on patent law; and secondly, it will be shown how the UPP is in itself a manifestation of the federalism that characterises the EU as a sui generis supranational organisation.

\section{The dream of a unitary patent system through the years}

Even though a well-developed EU patent law is a long-standing objective, dating back to 1973 , this process has not been easy due to political and technical issues as well as difficulties with translation. Therefore, there were many steps backwards and forwards. However, although the EU was unable to find permanent solutions to patent law, it does 
not mean that there were no developments at the European level. Firstly, it is important to note that different European countries have established national rules to protect inventions in their territories. Moreover, with the adoption of the European Patent Convention ${ }^{\text {II }}$ (EPC) in 1973, the protection of inventions is guaranteed by the European Patent Office ${ }^{\text {III }}$ (EPO) for the Contracting States which an applicant has designated; this extends to even non-EU Member-States, such as Norway and Turkey.

From 1973 (when the EPC was adopted) to 2013 (when the UPP was adopted), there were several developments in the evolution of the European Patent System (EPS). In 1975, the Luxembourg Convention was drafted with the aim of creating a European Patent system for the internal market, for trademarks, designs and models, but it did not enter into force. In 1989, a new version of the Luxembourg Convention came into existence, but it was not adopted, as it did not have the support of EU Member States (mainly because of the translation rules). Later, in 2000, the European Commission proposed a Community Patent Regulation, which aimed at creating a uniform patent protection that would be granted by the EPO. However, it was difficult for the EU to join the EPC. In 2003, there was an attempt to establish a unified jurisdiction for litigation of European patents - the European Patent Litigation Agreement by the EPO - but the EU Parliament had concerns about its compatibility with EU law and decided not to go ahead with it. Subsequently, in 2007, the Commission relaunched the initiative to create a single community patent and a single jurisdiction; this culminated with the proposal, in 2009, of the European and EU Patents Court Agreement, which will be presented further in more detail.

Even though national and European levels of protection are important, mainly to inventors and enterprises interested in protecting their patents, they do not help create coherence and cohesion in a field of law that would benefit greatly from such uniformity, especially in encouraging and attracting inventors to seek protection in the EU. Currently, the European Patent System (EPS) is characterised by a multi-level governance that is highly complex and fragile due to its parallel structures of national and European (but not EU) frameworks. ${ }^{\text {IV }}$ Due to this, the EU has been trying to create its own legislation of patent law, for which the existence of a specialised and common court for the MemberStates is essential to decide on any kind of judicial actions related with patent law.

Moreover, one must understand that the creation of a unitary patent title is not something that appears on its own, but is integrated with the europeanisation of Industrial 
Property Law. Indeed, in the EU legal order, there are already other unitary industrial property titles, such as the "European Union trade mark" (Regulation 2015/2424) or the "Community design" (Regulation 6/2002). As such, due to the crucial role that patents have in Industrial Property Law, the importance for the EU and for the functioning of the internal market to have Patent Law regulated by EU Law is evident, since it will allow an invention to be protected all over the EU territory, as it already happens with trademarks and designs.

The path however has not been easy; some proposals have already been discarded, but the most recent development on this subject, the UPP, has been drafted, approved and is ready to enter into force. ${ }^{\mathrm{V}}$

\section{The UPP regime}

The UPP contains two EU Regulations (Regulation 1257/2012 and Regulation 1260/2012) and an international agreement, which together create a unified patent court (AUPC). This agreement will only enter into force once it is ratified by thirteen MemberStates (including necessarily France, Germany and the United Kingdom, these being the Member-States with the highest number of patents granted in the year preceding the signing of the AUPC, as established by article 89). In addition to that, both EU Regulations will only become applicable when the AUPC enters into force [Article 18(2) of Regulation 1257/2012 and Article 7(2) of Regulation 1260/2012].

The UPP arises from a need to overcome the problems of the EPS, specifically the European Patent Convention. It unifies the patentability requirements and has a unified procedure of granting patents, whereas currently the effects of a patent are national, including the rules regarding infringement and/or the invalidation procedures. The current system consists of a double pillar structure: an intergovernmental EPO, based on the EPC; and a supranational EU, where there is some harmonisation of patent law, such as in the field of biotechnological inventions and remedies for patent enforcement (Baldan and Van Zimmeren 2012: 1542). The ECJ does not have competence to deliver preliminary rulings, and it is up to national judges to decide on the interpretation of national patents. Several problems arise with this system; these are mainly related to a divergence of decisions, an incoherence throughout the system, and the existence of parallel litigations. Additionally, it 
allows some parties to abuse the system through litigation strategies such as forum shopping, where litigators can choose a jurisdiction likely to be favourable to them, and torpedo motions, where litigators, in order to impede a resolution, choose jurisdictions known for their long procedures. Moreover, there are some accusations that the Board of Appeal of the EPO lacks judicial independence, which deeply affects its credibility (Baldan and Van Zimmeren 2012: 1529-1533). This has led to the creation of a unitary patent system that attempts to overcome some of these problems, although it might create others.

\subsection{Regulation $1257 / 2012$}

A European patent with unitary effect (European Unitary Patent) is not necessarily a unitary patent; instead, it provides uniform protection to and has equal effects in all the participating Member States [Article 3(2) of Regulation 1257/2012]. Basically, it does not imply the creation of a new legal title, but the effect it has throughout the EU is what changes (Gonçalves 2015: 83-85). Whilst previously the EPS worked through the granting of a bundle of patents (also known as classic European patents), with each and every one of them requiring validation in the designated Member-States as well as translation to the official language of that specific country, currently the system converges at the EPO, through a single application, and is automatically effective in the designated MemberStates.

An applicant can file a request with the EPO for the patent to have unitary effect, within a month of the granting of a classic European patent [Recital 18 of Regulation 1257/2012]. If an application is made and if all the requirements are met, then the patent is registered as a European patent with unitary effect in the participating Member-States. However, even without filing a request, an applicant can still have a bundle of national patents that will be subject to the UPC, if the country has adhered to the system.

The prospective European Unitary Patent will be automatically validated in the participating Member States, in the official language of the EPO, in which it will be granted. It will coexist with national patents of Contracting States that do not belong to the EU or that, although belonging to the EU, have not adhered to the enhanced cooperation. Additionally, it does not replace the national patents granted by the Member-States. For example, there can be a unitary patent in participating Member-States, plus a classic 
European patent taking effect in one or more EPC Contracting States, such as Norway, Spain, Switzerland and Turkey.

This will lead to several layers of protection of patents in the territory of the European Union: (a) national patents, granted by national offices and subject to national jurisdiction; (b) classic European patents without unitary effect, granted by the EPO and subject to the UPC jurisdiction; (c) national patents that are part of the bundle granted by the EPO and not subject to the UPC (either because the patent owner opted-out, the AUPC has not been ratified in a particular State or the country is not an EU Member); and (d) European Unitary Patents, granted by the EPO and subject to the UPC (Baldan and Van Zimmeren 2012: 1542-1546). Some experts say that this will lead to an even greater fragmentation of the system (Silva 2012: 254-255), as it will involve different judicial reviewers of the patent framework (Baldan and Van Zimmeren 2012: 1542-1546). ${ }^{\mathrm{VI}}$

The fees required for the granting of a European Unitary Patent will be paid to the EPO, which will retain 50 per cent and distribute the rest to the Member-States [Article 13 of Regulation 1257/2012]. ${ }^{\mathrm{VII}}$ This requires a delicate balance between the will to make the Unitary European Patent attractive to users/enterprises, and the EPO's budget, without overlooking the funding of national patent offices.

It will also mean that the EPO will take on a number of additional tasks. It will administer patentees' requests for unitary effect; it will also be responsible for collecting and administering renewal fees for unitary patents and for keeping a register of unitary patents, which will include legal-status information such as licences, transfers, limitations, revocations or lapses [Article 9 of Regulation 1257/2012].

\subsection{Regulation $1260 / 2012$}

Additionally, a translation system was created to complement the European Unitary Patent, to ensure that problems arising from the different languages of the Member-States do not hinder an effective application of the UPP.

According to article 14 of the EPC, English, German and French are the official languages of the EPO, and a patent application may be filed in one of the official languages. If it is not filed in one of these three languages, a translation should be made. This entails higher costs for patent applicants, but that has been reduced by the translation regime adopted in Regulation 1260/2012 of the UPP. It provides for a transitional period 
of 6 to 12 years, where, if the language of the proceedings at the EPO is French or German, then the patent proprietor will have to provide a translation into English; or if the language of the proceedings is English, then the patent proprietor will have to provide a translation into any official language of the European Union. In case of a dispute, either at the request of the court or of an alleged infringer, the patent proprietor will have to provide a full translation into the relevant language [Article 4 of Regulation 1260/2012].

In an effort to protect inventions, to help technological advance and to make the system attractive for everyone, reimbursements for translation costs will be available up to a certain ceiling, for small and medium enterprises (SME's), individual persons, nongovernmental organisations (NGOs), universities and research public entities [Article 5 of Regulation 1260/2012]. Additionally, mechanisms of high-quality automatic translations, called Patent Translate, will be put in place to facilitate translations. ${ }^{\text {VIII }}$ It will ultimately lead to a situation where a European patent applicant will no longer have to fulfil a translation requirement, making it less costly, easier to access and legally secure.

\subsection{AUPC}

As discussed, the UPP includes the creation of a common and specialised court that is essential to guarantee the desired uniformity and coherence in the EPS. This is in accordance with the idea of the UPP, since what has been created is a supranational patent law, whereby national courts are not deemed suitable to decide on the possible disputes that could arise from what is established by the EU Regulations. This is similar to the solution achieved by the Patent Law of the USA, where the federal courts have national jurisdiction over patent disputes throughout the territory of the USA.

The path leading to the UPP has not been easy and this is particularly so in relation to the creation of a supranational court like the UPC. In 2009, EU institutions presented the European and EU Patents Court Agreement (EEUPC); it consisted of an international agreement to be concluded between the Member-States of the EU, the EU in its own legal capacity and third countries who are parties of the EPC. The main objective of this agreement was the creation of a court with jurisdiction to hear litigation related to the European patent and the future Community patent and, consequently, the creation of an extremely complex system of granting patents issued by the EPO. 
However, the CJEU found this agreement incompatible with the Treaties of the EU in its Opinion 1/2009. ${ }^{\mathrm{IX}}$ In essence, this decision results from the fact that such a Court would be an international court, neither integrated with an EU judicial order, nor subjected to EU law. Moreover, it would deprive national courts of the power, or, as the case may be, the obligation, to refer questions to the Court for a preliminary ruling in the field of patents. Thus, and due to the possible negative and unprecedented consequences that such an international agreement could bring to the EU legal and judicial order, the proposal was rejected [Opinion 1/2009 paragraphs 64 to 73].

Nevertheless, the CJEU did not oppose the creation of a common and specialised court in the field of patent law; its decision only related to the concrete configuration of the EEUPC, namely the threats it posed to the EU legal and judicial order. Accordingly, it is possible to find some guidelines in Opinion 1/2009 for how, in the perspective of the CJEU, EU institutions could redesign such agreement [Opinion 1/2009 paragraphs 74 to 88]; and the solution was the AUPC. ${ }^{\mathrm{x}}$

The AUPC is an international agreement comprising all the EU Member-States that participated in the enhanced cooperation to create both of the EU Regulations, with the exception of Poland. Its main purpose is the resolution of disputes concerning European Unitary Patents (its exclusive competence is established by article 33 of the AUPC), but, since it is a common court of the EU Member-States, the UPC is subject to the same obligations as the national courts of the Member-States [Articles 20 to 23 of the AUPC].

The institutional aspects of the UPC are established by articles 6 to 14; and it comprises a Court of First Instance, a Court of Appeal with a seat in Luxembourg, and a Registry. The Court of First Instance has a central division (with a seat in Paris and sections in London and Munich) as well as local and regional divisions that can be created at the request of Member-States. Equally significant is Article 24, since it clarifies which legal instruments the UPC should use in its decisions: (i) European Union Law, including the EU Regulations of the UPP; (ii) the agreement itself - Articles 25 to 30 and 62 to 69 are substantive rules; (iii) the EPC; (iv) other international agreements applicable to patents and binding for all the Contracting Member States; (v) national law. Extremely pertinent to the UPC jurisdiction is its transitional regime, established in Article 83, which allows for an opting-out from the jurisdiction of the UPC within seven years, as an attempt of adaptation to this new and innovative legal framework. ${ }^{\mathrm{XI}}$ 
Even though the AUPC is flawed, as it does not count on the participation of all EU Member-States and is based on several legal sources, the purpose of the UPP and specifically the UPC is clear: to have a single, common and specialised court to deal with disputes concerning patent law in the EU, in order to promote coherence and uniformity in this field. It is ultimately, in our understanding, a manifestation of federalism, as will be explained below.

\subsection{The advantages and disadvantages of UPP to EU Patent Law}

Our analysis of the UPP, with its two regulations and international agreement, is not confined to its shortcomings, but also presents some benefits for the system as a whole.

Firstly, the establishment of a European Unitary Patent would provide for uniform protection in a wide territorial space: the EU. Inventors would be able to apply for a unitary patent that would be effective in the countries that are part of the UPP. This would also be cheaper in terms of the fees and because there would be no need for translations to be made, after the stated transitional period. Correspondingly, a simpler procedure would be established at the EPO, which would not require a validation at the national level, would be less time-consuming and avert the risk of parallel applications.

Secondly, the fact that a unitary and specialised jurisdiction would be created would lead to the improvement of judicial coherence, and consequently ensure the consistency of case law (Baldan and Van Zimmeren 2012: 1565-1571), leading to legal certainty and uniformity of decisions. It would raise the level of trust that inventors would place in the new system, as well as ensuring that their inventions are effectively protected against infringement. Furthermore, it would certify that the same standards of adjudication were met, instead of having different standards for different Member-States. This would truly promote a culture of protection for scientific and technological development, which the EU requires to stand on par with other world economies.

Finally, there are a lot of questions about the EPO's independence, especially considering the Boards of Appeal, which cannot be scrutinised by the CJEU, since the EPO is an intergovernmental organisation outside the EU. With the new system, the EPO would be subject to EU standards, through the aforementioned regulations and the referrals to the CJEU, thus ensuring accountability, as independence of the judiciary is a 
fundamental human right that cannot be disregarded (Baldan and Van Zimmeren 2012: 1564).

However, the problems that arise from this new system cannot be ignored, mainly due to the coexistence of several layers of protection. As we have said, this new regime is based on the EU mechanism of enhanced cooperation, meaning that only the Member-States that want to participate will ultimately participate and be subject to it. Some countries, such as Poland, ${ }^{\mathrm{XII}}$ Croatia ${ }^{\mathrm{XII}}$ and Spain, ${ }^{\mathrm{XIV}}$ have decided not to be included in a part or the whole of the system, leading to difficulties in coordinating the different regimes available to patent applicants and perhaps a greater level of fragmentation than the one that the Member States wanted to avoid when they entered the UPP (Silva 2012: 254-255).

Another criticism of the UPP is that significant parts of the substantive framework of the European Unitary Patent, such as the definition of the rights of the owner of the patent and its limitations, namely Chapter V of the AUPC, are established in the international agreement. By not being established by an EU instrument, these sections cannot be subjected to the interpretation and appreciation of the ECJ, since the ECJ has no jurisdiction over an international agreement; this becomes problematic when considering fundamental rights, as was discussed supra. Additionally, unlike EU regulations, an international agreement cannot be altered easily by the EU Parliament, thus putting in question the democratic principle. The AUPC tries to overcome this problem by establishing the primacy of EU law and liability for damages caused by infringements of EU law [Articles 20 to 24 of the AUPC] and also by allowing the UPC to request for preliminary rulings of the CJEU that will be binding to the court [Article 21 of the AUPC]. In regard to the two regulations, they can be subject to the ECJ for a preliminary ruling since they are regular EU instruments.

By minimising the role of the CJEU, through concentrating all case law related to patents in a specialised court, the AUPC prevents national and general courts from deciding on specific matters such as patent law, since national judges do not usually have much knowledge of the particulars of this field. The judges presiding in the UPC will be highly specialised and qualified in this matter and will be vital in standard-setting.

However, national institutions, such as courts, legislators and organisations that deal specifically with patents, have an important role in the Member-States, in particular, to include socio-economic considerations and national needs in their patent policies (Xenos 
2013: 253). Not submitting the specialised court to the scrutiny of the CJEU, especially in the interpretation of the AUPC, means that some broader questions related to EU institutional design, to the specific policies of the Member-States and mainly in regard to fundamental rights, can be overlooked in a court specialised in patent law that is not the CJEU.

These issues, along with the plurality of legal sources (international, EU and national) and the non-application of the AUPC to all EU Member-States, are the weak points of the AUPC. However, it cannot go unremarked that the AUPC was shaped based on Opinion $1 / 2009$, which is closely connected with the EU framework, to ensure accountability and standard-setting in the patent field.

This brief exposition of the advantages and disadvantages of the UPP concludes that the system is not perfect. In our opinion, it has some flaws, mainly regarding the different frameworks that will be at play, but it presents benefits for inventors, who ultimately have to be protected and their rights ensured in the EU. The other benefit is to the EU, which, as a single market, will be more competitive than other markets.

\section{The UPP as a federal manifestation}

\subsection{The USA as a paradigm ${ }^{\mathrm{Xv}}$}

The federal nature of the United States is also expressed in its patent law, where instead of assigning the power to grant and enforce patents to the states, the USA's legal patent framework relies on federal institutions. When an inventor wishes to protect an invention, the request is made to the United States Patent and Trademark Office (USPTO). Once granted, as a product of the harmonisation of international instruments, the protection lasts for 20 years from the filing of the patent; and the patent is effective throughout the United States, USA territories, and USA possessions. The power to enact laws relating to patents belongs to Congress, and patent law is currently codified in Title 35 of the United States Code. This means that patents are exclusively governed by federal law, and state law basically plays no part in patent law.

The USPTO has a number of functions that are similar to the ones the EPO will have when the UPP comes into effect. It administers patent laws, examines applications for patents and grants them when all conditions are met. It also records assignments of 
patents, maintains a collection of issued patents and records, which the public can access, and supplies copies of records and other documents on request.

However, the USPTO has no jurisdiction over questions of infringement and the enforcement of patents, although, through its Patent Trial and Appeal Board, it has some additional competences in post-grant proceedings. ${ }^{\mathrm{XVI}}$ When a patent is infringed within the USA, federal courts have exclusive jurisdiction over patent infringement. According to the rules of procedure, a district court is the starting point, with the possibility of appeal to the Court of Appeals for the Federal Circuit, created in 1982, and then to the Supreme Court.

The pertinence of the USA patent system to this discussion is that it is based on two federal characteristics: patent laws are federal laws and infringement cases are the exclusive jurisdiction of federal courts. In this sense, a patent is granted for the entire of territory of the USA and not only for a designated State; and an infringement can affect the whole of the USA. It would not make sense to for applicants to request a patent and to have it validated in all the 50 States or in the ones it designated; besides being costly, it would also be time consuming and unattractive for inventors. This leads us to conclude that a similar process is being tried out in the EU, with its own characteristics, as might be expected from a sui generis organisation.

\subsection{Why is the UPP a manifestation of federalism?}

It seems certain that, at least from a formal and legal perspective, the EU is not a Federation. Nevertheless, that does not mean that this supranational entity does not have federal manifestations, which are increasingly confirmed with developments in the EU after the Lisbon Treaty.

It is our understanding that one of the major problems in the discussion of the EU as a Federal Organisation is related to comparing the EU with one of the most developed federations: the USA. If that approach is taken, the EU is certainly not a federation: there is neither an elected federal government, nor a President of the EU; the Member-States have their own sovereignty (much wider if compared with the sovereignty of the States of the USA); and it is mainly up to the Member-States to enforce its laws, rather than the EU itself. Moreover, it should not be forgotten that the USA has built itself from scratch as a federation, whilst the continent of Europe has been devastated by sovereign States fighting amongst themselves for centuries and where, since the Roman Empire, there has not been 
a common political and economic project. Currently, even though there is a European cultural core, there are also numerous cultural, economic and political differences between the nationals of different EU Member-States.

Nevertheless - and that is our starting point - for the EU to be considered as a Federal Organisation, it does not need to be equal to the USA. Additionally, as pointed out by Pierre Pescatore:

'federalism is a political and legal philosophy which adapts itself to all political contexts on both the municipal and the international level, wherever and whenever two basic prerequisites are fulfilled: the search for unity, combined with genuine respect for the autonomy and the legitimate interests of the participant entities' (Pescatore 1982: ix-x).

In a similar sense, Daniel Elazar maintains that the EU is 'already a federalism' (Elazar 1979: 3) and we are in full agreement. From a general point of view, the EU is a federation with its own characteristics, and specifically, the UPP being a clear manifestation of this, since the prerequisites pointed out before are fulfilled.

Even though we agree with such opinion, it is important to see other perspectives, especially those which do not frame the EU as any kind of a federation or those which are sceptical of it. First of all, it is clear that the "federal question" is not consensual amongst EU Member-States; Brexit is a classic example, but is not the only one (Hungary's present government or the support that Marine Le Pen obtained in the most recent French elections are also indications of the discontent of some European citizens with EU policies).

One must understand that many countries are unwilling to either give more powers to the EU or to change the decision-making rules, for example, by eliminating the national veto. Some think that further integration is neither needed nor desirable, whilst others believe that the EU is a threat to either national identity or to the security of workers and ordinary citizens, as suggested by the surge of far right and left populists in the last European elections (Borrel, 2015). Moreover, it should be noted that all EU MemberStates are not at the same stage of development (something that the recent financial crisis came to accentuate), which does not help as a starting point to achieve complete integration. 
Due to these factors, the idea of the EU as a federation could seem a little odd and difficult to conceive, which leads to some preferring a Europe of nations, since 'Europe would be more prosperous and democratic if each nation provided for its own needs' (Hannan, 2014). As such, we must be aware that there are not only those who refuse to see the EU as a federation (even though conceptually different from the federalist paradigm), but there are also those who are against the federal manifestations. In essence, those that do not desire more federal elements argue that there is not a demos to European democracy, since there is neither European people, nor a European identity (akin to national ones), thus not making sense to promote a Federation without those (and others) elements.

Whilst it would be easy to let ourselves fall for these arguments, we are not in agreement with them. Firstly, we believe that there is a European identity, with its core values of freedom, justice and rule of law; and even though a German might be very different from a Spaniard or a Swede from a Greek, there are ties that unite the different nationals of EU Member-States. Besides that, we should not forget that, even in the USA a classic model of federalism - the "nationals" of the different States are not the same in many respects. Moreover, we do not see those elements as mandatory, instead, we perceive as more important the will of the nationals of EU Member-States in having a more federal EU by democratic expression. Finally, it is important to stress the idea that the EU is a supranational entity with no parallel in world history and, as such, we must not expect that the possible federal course of the EU to be the same as other entities. Nevertheless, what is undeniable is the existence in the EU of federal manifestations, the UPP being one of them.

Returning to Pescatore's prerequisites, it is our understanding that the UPP fulfils both of them and, as such, it could be framed as an EU federal manifestation. Firstly, it represents a 'search for unity', since its main purpose is to provide a mechanism to protect inventions with a European Unitary Patent and, therefore, enforceable all over the EU. Moreover, due to the UPC, the judicial coherence in EU patent law will be promoted with the settlement of a dispute by a common court of the Member-States. With this in mind, it is possible to state that the UPP signifies a way for Member-States to jointly overcome a problem and, by that, promote a uniform legal and judicial system.

Whereas the search for the unity prerequisite must be absolute, since the pursuit of a common objective cannot be subordinated by other principles, the same does not apply to 
the second prerequisite. The 'genuine respect for the autonomy and the legitimate interests of the participant entities' should be pursued, but also balanced with other interests, because if an individual approach is adopted, this becomes an impossible prerequisite to fulfil. This condition must be balanced with the objectives which are subsumed by the search for unity, since in practical terms it is very difficult to coordinate the concerns of all the Member-States. In this sense, it is crucial to respect their interests and autonomy, but it is also important that these are not used to block the search for unity and, thus, the Member-States must adopt a wide perspective to achieve common interests.

The UPP is the result of long and intense negotiations which were only possible due to the mechanism of enhanced cooperation, but with the participation of an overwhelming majority of the Member-States (25 out of 28). This shows that almost all the MemberStates are following the same path in relation to patent law, that is, a system of unitary protection.

At the same time, there are some aspects of the UPP, for example, the translation system addressed before, which show a respect for the sovereignty and autonomy of Member-States. In addition to that, it is important to see that the European Unitary Patent is an option and not an obligation, since patent applicants can choose whether or not to submit their inventions to such protection. Finally, article 7/4 and 5 of the AUPC, which allows Member-States to request the creation of local or regional divisions of the Court, shows an effort to integrate the idea of proximity that would be achieved with the federal structure of the UPP.

In sum, the UPP could be framed as federal, since it promotes unity and uniformity for a matter that is relevant to the single market and to the scientific and technological development of the EU by transferring Member-States' powers in this field to the EU, the EPO and the UPC. However, this is done in a comprehensive and progressive way to respect the sovereignty and autonomy of the Member-States, which leads us to the conclusion that the UPP is a manifestation of a sui generis federalism that characterises the EU of today.

\subsection{What currently stands between full federalisation and the present regime}

As pointed out before, uniformity and coherence are significant in an economic and political union such as the EU, since it is important for inventors and enterprises to know 
that they can protect their inventions throughout the territory, via both administrative and judicial proceedings, as established by the UPP. However, due to the difficult path that patent law has followed in Europe - with national and European, but not EU, protection the current system, as we have explained, is a highly-fragmented EPS.

One can understand that this starting point is not ideal to promote and achieve the desired objectives under a federal structure, especially because the present European protection provided by the EPC is not exclusive to EU Member-States. It is based on an international convention, which means that the EU does not have powers to revoke it and replace with its own laws. Moreover, it would be unreasonable to dispense the forty years of experience of the EPC and EPO, highly valuable in establishing a new regime. That is why there are several layers of protection that co-exist as discussed earlier.

With this in mind, it is possible to understand that a clear and full federalisation (like the one that exists in the USA) is near-impossible to achieve, with the existing configuration of the EPS, due to the co-existence of different layers of protection. In addition, even if we focus only on the EU, the federalisation process is not complete. For example, some Member-States do not belong to the UPP, such as Spain, Poland and Croatia, affecting the legitimacy of the new regime and imposing obstacles in its path. ${ }^{\text {XVII }}$ The EU must work to convince these States to join the UPP's framework, where the participation of all EU Member-States would be extensive.

Some authors claim that the coming into force of enhanced cooperation on this issue is a 'dark day for European integration' (Lamping 2011: 36), however, we do not agree. It is certain that a "Europe à la carte" is not desirable, but what is also not intended is a Europe which cannot keep pace with developments in the rest of the world and that does not promote an adequate protection to scientific and technological development. It should be noted that, for obvious reasons, enhanced cooperation is not a solution for all the problems of the EU, especially considering the rupture that the EU is experiencing; nevertheless, in a situation like the one at hand, considering specifically patent law, we think that it is a fair and reasonable solution, especially as a vast majority of Member-States is intent on participating in the UPP, and a few Member-States should not be allowed to impede the interests of a vast majority.

Moreover, the fact that a patent with unitary effect is optional is a potential weakness of the system, since it is left to applicants to decide whether to ask for a unitary effect or 
not. Although this is true, we cannot ignore the benefits that the regime would bring for businesses, inventors and society as a whole, that will ultimately lead to a choice for unitary application, and consequently a peaceful and complete integration.

There are others concerns, namely Brexit, that might jeopardise the effectiveness of the UPP. However, the current EPC-based system will not be affected by Brexit, since it is established by an instrument of international law and not EU law, it is not restricted to only EU Member-States, thus allowing the UK to participate. Nevertheless, the AUPC entry into force is dependent on the ratification of the United Kingdom, required for both Regulations 1257/2012 and 1260/2012 to become applicable, as seen before. The UK has already expressed its intention to continue participating in the UPP, ${ }^{\mathrm{XVIII}}$ but this raises some additional issues, since enhanced cooperation is a mechanism of the EU legal order and the AUPC is a common court of EU Member-States. A new agreement, or some structural changes to the AUPC (Gordon and Pascoe 2016) might be needed to resolve the question of the UK's participation, since the UK is one of the countries with the highest number of patent applications in the EU, and since one of the central divisions (Life Sciences/Chemistry section) of the Court of First Instance will be located in London.

One could conclude that what stands between a full federalisation (if we base our perspective on the paradigm presented by the USA) and the current legal order of the EU are the same aspects that give a federal dimension to the UPP. This could seem contradictory, but it is not. The federalism in the EU is not as it is in the USA, but that does not erase the existence of federalism in the EU: it exists due to the fact that there is a search for unity in this area, balanced with a respect for the different concerns and interests of its Member-States, even if it does appear to have a federal structure as we are used to.

\section{Conclusion}

It is our understanding that federalism should be increasingly discussed in the EU and not treated as a taboo subject regardless of the existence or lack of federal elements. Nevertheless, we must not forget that, more and more, globalisation is reshaping the political, economic and social destinies of the world, with new international actors and, as such, the nations of Europe can only safeguard their prosperity and their social 
achievements by joining forces and standing together on several key issues. This requires, sooner or later, new steps towards a federal union (Borrel 2015).

Our goal with this paper was to establish a connection with the UPP and with a soaring reality that is the EU, as a sui generis federation. Through a solid analysis of the UPP and its integrating components, it is possible to understand the advantages that a reshaped system can bring to the single market and the promotion of scientific and technological developments in the EU. As was demonstrated, it must be reiterated that patents with unitary effect will not be the only unitary title in Industrial Property Law, as it will add to a harmonised system of both EU trademarks and designs, strengthening it, that shows the relevance of this step forward. Nevertheless, it cannot go unnoticed that there are still some obstacles that prevent this system from reaching its true potential. The coexistence with an international agreement, like the EPC, the different judicial reviewers and the nonparticipation of all the EU Member-States in the framework of the UPP represent some of these obstacles.

Despite these challenges, the post-UPP European Patent System will be more coherent, uniform and adapted to the single market, which is an economy with even more worldwide impact. As such, the overwhelming majority of EU Member-States are interested in this cooperation, only if complemented with the respect for their sovereign interests (as it is in the present case). In conclusion, and defending an approach which concentrates the subject-matter of a federation in a clear search for unity, we sustain that the UPP is an EU federal manifestation.

\footnotetext{
* Master candidates in International and European Law at Nova Lisboa School of Law.

I The Unitary Patent Package consists of two EU regulations (European Parliament and Council, Regulation (EU) 1257/2012 of the European Parliament and of the Council of the EU of 17 Dec. 2012 implementing enhanced cooperation in the area of the creation of unitary patent protection, O.J 2012 L361/1 (hereinafter "Regulation 1257/2012"), Council of the EU, Council Regulation (EU) 1260/2012 of 17. Dec 2012 implementing enhanced cooperation in the area of creation of unitary patent protection with regard to the applicable translation arrangements, O.J.2012, L 361/89 (hereinafter "Regulation 1260/2012") and an international agreement between EU Member States (Agreement on a Unified Patent Court, O.J. 2013, C 175/1 (hereinafter "AUPC")).

II Convention on the Grant of European Patents - (European Patent Convention) of 5 October 1973 as revised by the Act revising Article 63 EPC of 17 December 1991 and the Act revising the EPC of 29 November 2000. It is a treaty to which 38 States, including all the Member States of the European Union (but not the Union itself) are currently parties. Available in: http://www.epo.org/law-practice/legaltexts/html/epc/2016/e/ma1.html.

III More about the EPO in: https://www.epo.org/about-us.html.

IV More about the "Current European patent system" see: Baldan and Van Zimmermen 2015: 1541-1556.

$\mathrm{V}$ As of $15^{\text {th }}$ of May 2017, it is expected to enter into force in December of 2017: https://www.unifiedpatent-court.org/news/final-preparatory-committee-signals-state-readiness-15-march-2017
} 
VI National courts with respect to national patents; the Boards of Appeals regarding European patents; national courts of the EU Member-States, which did not ratify the AUPC or did not participate in the enhanced cooperation; the UPC deciding on matters related to the infringement and validity of classic European and unitary patents for the Member-States who ratified the AUPC; the European Court of Justice for UPC requests for a preliminary ruling.

VII Article 13 Regulation 1257/2012, distribution of the fees, is based on the following criteria: "(a) the number of patent applications; (b) the size of the market, while ensuring a minimum amount to be distributed to each participating Member State; (c) compensation to the participating Member States which have: (i) an official language other than one of the official languages of the EPO; (ii) a disproportionately low level of patenting activity; and/or (iii) acquired membership of the European Patent Organisation relatively recently". VIII The translation of patent documents is available for 28 official languages of the EPO's 38 member states, plus Chinese, Japanese, Korean and Russian - http://www.epo.org/searching-for-patents/helpfulresources/patent-translate.html\#tab3.

IX Opinion 1/2009 of the Court (8 March 2011) EU:C 211/03 referred to as Opinion 1/09.

$\mathrm{x}$ Too more details on the impact of the Opinion 1/09 to the AUPC, see Baldan and Van Zimmeren 2012: 1558-1559.

XI The aspects of the AUPC here presented are the most significant ones. For more details see, Baldan and Van Zimmeren 2012: 1560-1564; SILVA, 2012: 249-255; VICENTE 2015: 760-767.

XII Part of the enhanced cooperation, but not of the AUPC.

XIII Entered the EU after the signature of the AUPC.

XIV Strongly against the UPP, as seen by the annulment actions proposed in the ECJ: Spain v. Parliament and Council (Case C- 146/13 (5 May 2015), Kingdom of Spain v European Parliament and Council of the European Union, EU:C:2015:298, referred to as Spain v. Parliament and Council); Spain v. Council (Case C-147/13 (5 May 2015), Kingdom of Spain v Council of the European Union, EU:C:2015:299, referred to as Spain v. Council).

$\mathrm{xV}$ The goal of this paper is not to establish a detailed comparison with the USA's regime, so an exhaustive analysis will not be made. We based our analysis on the website of the USPTO https://www.uspto.gov/patents-getting-started/general-information-concerning-patents\#heading-1.

XVI To see more about post-grant proceedings in the USA: TURCHYN 2016: 1497-1530.

XVII Such as the annulment actions brought to the ECJ by Spain.

XVIII https://www.gov.uk/government/news/uk-signals-green-light-to-unified-patent-court-agreement, although some delays are now expected, because of the UK's general election.

\section{References}

- Baldan Federica and Van Zimmeren Esther, 2015, 'The future role of the unified patent court in safeguarding coherence in the european patent system', Common Market Law Review, LII(6): 1529-1578.

- Borrel Joseph, February 2015, 'Is a Federal Europe Possible?", available at: https://www.thenewfederalist.eu/is-a-federal-europe-possible.

- Elazar Daniel, 1979, 'Options, Problems and Possibilities in Light of the Current Situation', in Elazar (ed), Self Rule - Shared Rule, Turtledove Publishing, Ramat Gan, 1-13.

- Gonçalves Luís M. Couto, 2015, Manual de direito industrial: propriedade industrial e concorrência desleal, $6^{\text {th }}$ ed., Almedina, Coimbra.

- Gordon Richard and Pascoe Tom, September 2016, 'The effect of 'BREXIT' on the Unitary Patent Regulation and the Unified Patent Court Agreement', available at http://www.bristowsupc.com/assets/files/counsel s $\% 20$ opinion $\% 20$ on $\% 20$ effect $\% 20$ of $\% 20$ brexit $\% 20$ on $\%$ 20upc, $\% 2012 \% 20$ sept $\% 202016$.pdf.

- Hannan Daniel, April 2014, 'Plea against a Federal Europe', available at: http://www.theeuropeanmagazine.com/daniel-hannan--2/8342-plea-against-a-federal-europe--2.

- Lamping Matthias, October 2011, 'Enhanced Cooperation - A Proper Approach to Market Integration in the Field of Unitary Patent Protection?', published in 42 IIC 2011, 879, 1-58, available at SSRN: https://ssrn.com/abstract $=1946875$. 
- $\quad$ Pescatore Pierre, 1982, 'Courts and Free Markets', in Sandalow Terrance and Stein Eric (eds), Courts and Free Markets: Perspectives from the United States and Europe, Clarendon Press, Oxford, Vol.1, ix-x.

- Silva Pedro Sousa e, 2014, 'O Tribunal Unificado de Patentes', Revista de Direito Intelectual, No2014-I: 243-257.

- Turchyn Jennifer, 2016, 'Improving Patent Quality Through Post-Grant Claim Amendments: A Comparison of European Opposition Proceedings and U.S. Post-Grant Proceedings', Michigan Law Review, CXIV: 1497-1530, available at http://repository.law.umich.edu/mlr/vol114/iss8/4.

- Vicente Dário Moura, 2015, 'Patente Unitária, regime linguístico e jurisdição competente', in Estudos de Direito Intelectual em homenagem ao Prof. Doutor José de Oliveira Ascensão, Edições Almedina, Coimbra, 733-760.

- Xenos Dimitris, 2013, 'The European Unified Patent Court: Assessment and Implications of the Federalisation of the Patent System in Europe', SCRIPTed - Journal of Law, Technology \& Society, X(2): 246-277, available at SSRN: https://ssrn.com/abstract $=2324123$.

Legislation, case-law and EU press releases (chronological order)

- $\quad$ Council of the EU, Council Regulation (EC) No 6/2002 of 12 Dec. 2001 on Community designs, O.J. 2002 L 3/1, referred to as "Regulation 6/2002".

- $\quad$ Opinion 1/2009 of the Court (8 March 2011) EU:C 211/03 referred to as Opinion 1/09.

- European Commission - "Press Release IP/11/269", Brussels (8 March 2011). Available in: http://europa.eu/rapid/press-release IP-11-269 en.htm?locale=en.

- Court of Justice of the European Union, "Press Release No 17/11", Luxembourg (8 March 2011). Available in: http://curia.europa.eu/jcms/upload/docs/application/pdf/201103/cp110017en.pdf.

- European Parliament and Council, Regulation (EU) 1257/2012 of the European Parliament and of the Council of the EU of 17 Dec. 2012 implementing enhanced cooperation in the area of the creation of unitary patent protection, O.J 2012 L361/1, referred to as "Regulation 1257/2012".

- Council of the EU, Council Regulation (EU) 1260/2012 of 17. Dec 2012 implementing enhanced cooperation in the area of creation of unitary patent protection with regard to the applicable translation arrangements, O.J.2012, L 361/89, referred to as "Regulation 1260/2012".

- Agreement on a Unified Patent Court, O.J. 2013, C 175/1, referred to as "AUPC".

- $\quad$ CJEU, Case C- 146/13, Spain v. Parliament and Council, 2015 EU:C:2015:298.

- $\quad$ CJEU, Case C-147/13, Spain v. Council, 2015 EU:C:2015:299.

- European Parliament and Council, Regulation (EU) 2015/2424 of the European Parliament and of the Council of 16 Dec. 2015 amending Council Regulation (EC) No 207/2009 on the Community trade mark and Commission Regulation (EC) No 2868/95 implementing Council Regulation (EC) No 40/94 on the Community trade mark, and repealing Commission Regulation (EC) No 2869/95 on the fees payable to the Office for Harmonization in the Internal Market (Trade Marks and Designs), O.J. 2015, L 341/21, referred to as "Regulation 2015/2424". 